\title{
Decision-Making in Defined Contribution Pension Plans: The Case of Israel
}

\author{
Ravit Rubinstein-Levi \\ Ben-Gurion University of the Negev
}

\begin{abstract}
Research suggests that the DC saving method, which is a self-guided saving method, is a contributor to exacerbation in retirees' poverty and income inequality. Economists lobby governments to provide the public with information regarding pension savings to improve the situation, and many studies conclude that employees can improve their decisions substantially by receiving pension advice. This study analyzes Israeli data of four field studies among over 1,500 subjects and the Israeli social survey data of the Israeli Central Bureau of Statistics (ICBS). The findings of the study indicate that providing employees with information regarding pension savings does not encourage them to more pro-actively manage their pension savings nor receive advice from a professional counselor. Surprisingly, the findings suggest that employees are more willing to receive pension savings advice from a counselor on behalf of the state than from a counselor who is not necessarily on behalf of the state.
\end{abstract}

Keywords: defined contribution, decision-making, pension, retirement, savings, advice

\section{INTRODUCTION}

The Defined Contribution (DC) savings method, which is implemented in most developed countries, is an important means of financing retirement consumption (Choi, 2015; Choi et al., 2004).

According to the DC saving method, the employees are required to make decisions with respect to the appropriate rate of savings, the appropriate investment choices, and the appropriate rate of post-retirement dis-savings (Bubb and Pildes, 2013). They are responsible for choosing their pension funds and pension schemes, and they bear the risks (Miles et al., 1999; Oehler and Werner, 2008; Knoll, 2010).

Research suggests that pension savings decisions require high levels of financial sophistication that most employees lack (Benartzi and Thaler, 2007; Lusardi and Mitchell 2009; Lusardi and Mitchell 2017; Agnew, 2013; Gharghori et al., 2008; Lusardi and Alessie, 2011; Van Rooij et al., 2012). Studies show that most employees are relatively passive investors, as they do not have well defined preferences, and the way things are presented to them affects their choices (Benartzi and Thaler, 2001; Benartzi and Thaler, 2002; Knoll, 2010; Choi et al.; Thaler and Benartzi, 2007; Harrison et al., 2006). When employees have preferences, they are often unclear and influenced by framing effects and starting points (Sunstein and Thaler, 2003). In many cases, employees tend to perceive the default as investment advice (Madrian and Shea, 2001; Carroll et al., 2009; Agnew and Szykman, 2005), and often the workplace makes an agreement with a pension fund, and the employees are not involved in the decision-making (Jenkins, 2005).

Studies conducted in most western countries point at the DC method as a contributor to exacerbation in retirees' income inequality, poverty, and dependence on government support (Been et al., 2017). Poverty 
rates among retirees are significantly higher than in the general population and are expected to increase in the coming years (Bleikh, 2016). Poverty projections in the United States predict that $33 \%$ of employees will be either poor or near-poor when they retire, and 55\% will rely only on their Social Security Income (Ghilarducci et al., 2015).

Since employees with more financial knowledge are more likely to be retirement-ready, to improve the situation, solutions that aim to improve financial literacy in the population are proposed (Lusardi and Mitchell, 2009; Lusardi, 2008; Burks et al., 2009; Lusardi and Alessie, 2011). However, performing such a task is difficult, prolonged, and expensive due to the complexity of the matter and its dynamic nature (Worthington, 2008).

Governments in the Organization for Economic Cooperation and Development (OECD) countries use various means to improve the financial situation of retirees. Tax incentives are the most significant incentive given by governments, designed to encourage employees to increase their pension savings and reduce their dependency on support payments (Harrison et al., 2006; Jenkins, 2005). However, most employees are so confused regarding the issue that they are almost unaffected by the incentives (Sewin, 2008). Other measures designed to improve the financial situation of retirees are compulsory pensions and age-adjusted default savings tracks. However, poverty rates among retirees continue to rise (Bleikh, 2016), and it seems that employees in most developed economies face a retirement crisis (Ellis et al., 2015).

The main objective of financial counseling should be to guide investors to make decisions that best serve their interests (Kahneman and Riepe, 1998). Mitchell and Smetters (2013) found that many employees are unable to make pension savings decisions without the help of professional counselors. Byrne (2007) found that employees who received pension advice, are more likely to calculate their savings needs, to achieve higher levels of knowledge in their investments, and to review them more actively than those who did not receive advice. Moreover, those who actively solicit advice are more likely to improve performance. Gunaratne and Nov (2015) found that the gap between participants' retirement goals and actual savings is smallest in the expert-advice condition. De Meza et al. (2008) found that most employees who receive financial advice are employees with high-income and high-education, therefore, expanding access to advice has a positive effect, particularly for the less financially literate (Hung and Yoong, 2013).

Behavioral economics can be used for designing effective prescriptive programs for economic decisions (Thaler and Benartzi, 2004). The usual route to behavior change in economics and psychology is by influencing the way people think through information (Dolan et al., 2012). Accordingly, economists lobby governments to provide the public with information regarding pension savings to increase and improve savings (Thaler, 1994).

Previous research suggests that the information acquisition process is highly dependent upon the manner in which information is presented (Painton and Gentry, 1985). Specifically, it was found that the way financial incentives for pension saving are presented to individuals, affects their choices, and information must be presented in formats that facilitate processing (Saez, 2009; Bettman and Kakkar, 1977).

The goal of this study is to examine whether the transfer of information regarding pension savings to employees can encourage them to manage their pension savings more pro-actively, and if so, does the approach used to transfer the information has an impact. Kahneman's theory of "thinking fast and slow" (2012) was used to design the information transfer approaches. Furthermore, due to the impact of professional advice on the effectiveness of pension savings (Byrne, 2007), the study also aims to find whether the transfer of information can encourage employees to receive pension savings advice from a professional counselor, and if so, does the approach used to transfer the information has an impact.

The experiments in this study were conducted in Israel, however, due to the similarity in the behavior of employees in Israel and in other OECD countries where the DC pension plans are implemented (Achdut and Spivak, 2010), the findings of this study may contribute to other countries as well.

\section{THE ISRAELI CASE}

Israel shares many similarities with other OECD countries. Israel is a member of the OECD with an economy that grew at an annual rate of 4\%, with GDP per capita equaling 37,200 USD in 2016. Moreover,

Journal of Applied Business and Economics Vol. 23(3) 2021337 
in 2016 household spending in Israel was $54.6 \%$ of GDP, similar to Germany and France, and to the EURO area where it was $54.5 \%$ of GDP ${ }^{1}$. However, in Israel, the ratio of the population whose income fell below the poverty line in 2016 was high at 0.177 compared to Germany, where it was 0.101 (2015) and France with $0.083^{2}$. Income inequality is also high in Israel, with a Gini coefficient of 0.35 in 2016 . Israel has a heterogeneous society, with large sections of the population considered poor. Specifically, the ultraOrthodox Jewish and traditional Arab sectors are poor due to low participation in the workforce and large families. As of 2017, about $49 \%$ of all Arab families and about $43 \%$ of all ultra-Orthodox Jewish families are considered poor ${ }^{3}$.

Israel has a well-developed financial system and uses many innovative financial instruments (Bodie and Merton, 1992). Like most other OECD countries, Israel implements the DC pension savings method. On January 1, 2008, the Israeli government instituted a mandatory pension law. There are different types of mandatory pensions. Like Austria, Belgium, France, Germany, Italy, Norway, Sweden, and the United Kingdom, the one implemented in Israel is income-related. The minimum rate of contributions for pension savings in Israel is $18.5 \%$ of the gross salary, of which the employee pays $6 \%$, and the employer pays $12.5 \%$.

In contrast to Israeli law, many employers do not contribute their part to the employee's savings account, a phenomenon that exists in other countries as well. Moreover, many Israeli employees avoid saving for retirement (Brender, 2011). As of 2015, approximately 40\% of Israeli employees do not save for retirement at all, primarily due to poor enforcement of the law. Therefore, the mandatory pension low in Israel does not succeed to significantly improve the state of all retirees (Gavious et al., 2009).

The maximum management fees in Israel are extremely high, $0.5 \%$ of the accrued reserve, and $6 \%$ of the contributions. For comparison, maximum management fees in Israel are more than twice the management fees in the United States, where small pension funds collect $0.4 \%$ management fees from the accrued reserve and up to $0.64 \%$ of the contributions. Large pension funds in the United States collect $0.15 \%$ of the accrued reserve and $0.42 \%$ of the contributions ${ }^{4}$.

Like other OECD countries' governments, the Israeli government uses the tax system to encourage pension savings. However, many Israeli employees find it difficult to comprehend tax incentives, and hence do not take advantage of them, as do employees in other OECD countries (Jenkins, 2005). Overall, Israeli employees behave much like employees in other OECD countries and avoid managing their pension savings (Achdut and Spivak, 2010). 62\% of Israeli employees with a pension arrangement have no idea what pension they will receive after retirement. $40 \%$ do not know what percentage of the salary they deposit to the pension fund, or how much of their salary they deposit to their pension fund. Moreover, $77 \%$ have no idea of the tax benefits deriving from the pension savings arrangement, and $68 \%$ have no idea of the rate of management fees they pay ${ }^{5}$.

The outcome is low pension coverage among employees, which leads to high poverty rates among retirees. Figure 1 illustrates the poverty rates in the total and the elderly Israeli population, before and after NII support payments for the years 2012-2018. 
FIGURE 1

\section{POVERTY RATES IN THE TOTAL AND THE ELDERLY POPULATION, BEFORE AND} AFTER NII SUPPORT PAYMENTS FOR THE YEARS 2012-20186

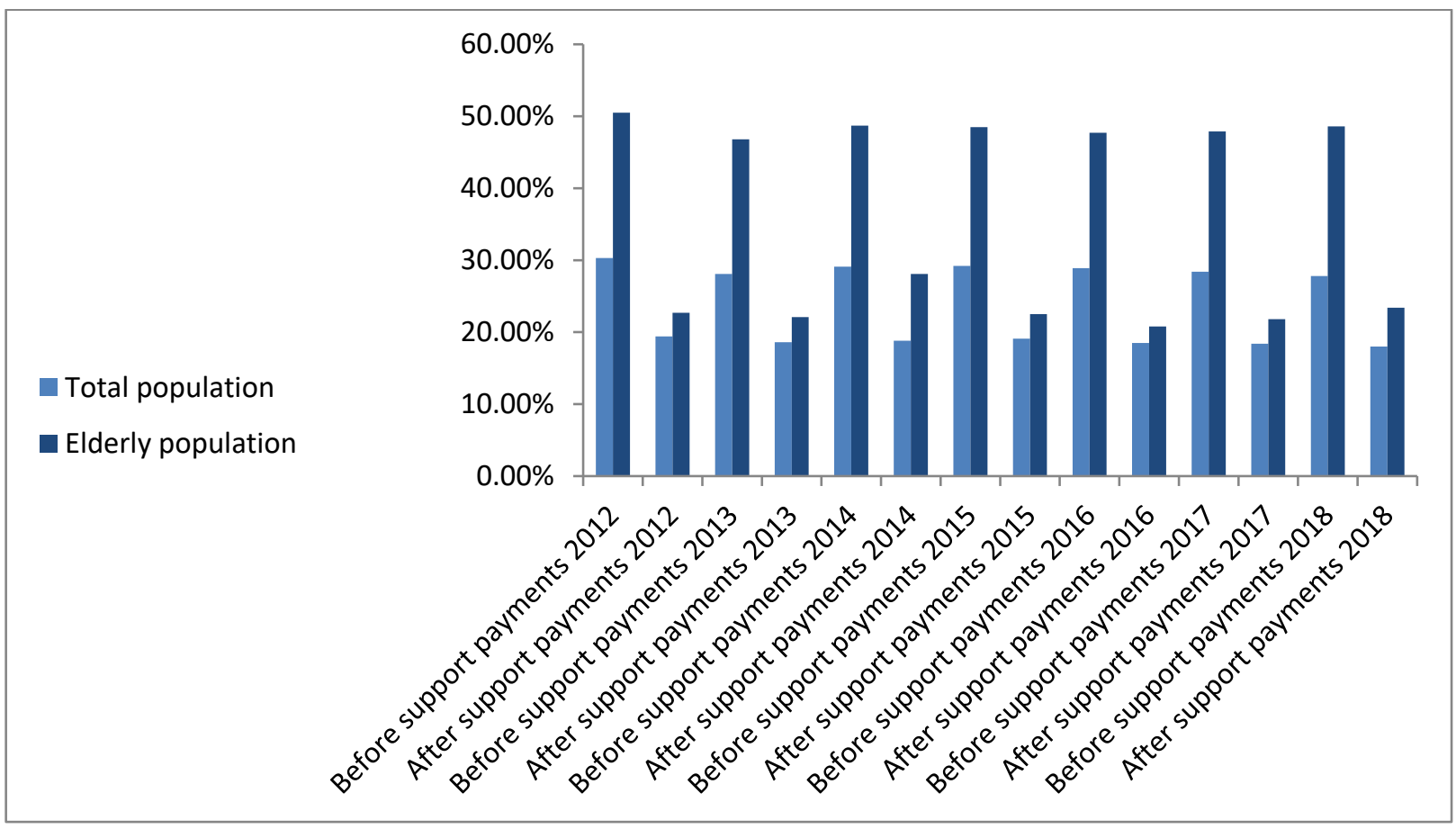

As can be seen from Figure 1, the income of about thirty percent of the total Israeli population would have been below the poverty line had it not been for the NII payments. That figure reduces to less than twenty percent once NII payments are accounted for. However, the income of about fifty percent of the elderly Israeli population would have been below the poverty line had it not been for the NII payments. That figure reduces to about 30 percent once NII payments are accounted for. It should be noted that, like other OECD countries, the medical expenses paid by the elderly in Israel are high (Baird, 2016).

\section{METHODOLOGY AND RESEARCH QUESTIONS}

\section{Data and Procedure}

This study was conducted in Israel in 2016 on a sample of Israeli employees with pension plans. The total number of respondents was 1,519. The sampling method used was convenience sampling, and the experiments were conducted using web-based survey software. The respondents received an email that contained a link, requesting them to click on the link and answer the questions that will follow. Four different links were sent to the respondents so that each respondent was linked directly to one out of four pre-determined groups. The groups were allocated using the random allocation method. The identity of the respondents remained anonymous. The data analysis was performed using t-tests for correlated samples and paired samples, t-tests for independent samples, and $\chi^{2}$ tests.

This study also uses data from the ICBS's social survey conducted in 2012, which is a representative sample of the Israeli population ${ }^{7}$, and included a section on retirement and pension savings. The purpose of the use of the ICBS's social survey is to compare some of the findings in this study to those of the social survey. Accordingly, some of the questions in this study were formulated precisely like some questions of the social survey. 


\section{Research Questions}

1. Can the transfer of information regarding pension savings to employees encourage them to manage their pension savings more pro-actively, and if so, does the approach used to transfer the information have an impact?

2. Can the transfer of information regarding pension savings to employees encourage them to receive pension savings advice from a professional counselor, and if so, does the approach used to transfer the information have an impact?

\section{The Manipulations}

Using Kahneman's theory of "thinking fast and slow" (2012), two manipulations were designed for the experiments. Kahneman's theory suggests that two "Systems" drive the way we think. "System 1", that is fast, intuitive, and emotional. It operates quickly and automatically, with little or no effort, and without a sense of voluntary control. "System 2" is more slow, deliberate, and logical. System 2 allocates attention to effortful mental activities. While System 1 runs automatically, System 2 is generally in a comfortable loweffort mode, and only a fraction of its capacity is engaged. System 1 constantly generates suggestions for System 2 in the form of impressions, intentions, intuitions, and feelings. If endorsed by System 2, intuitions and impressions turn into beliefs, and impulses turn into voluntary actions. Since System 1 operates automatically and cannot be turned off, errors of intuitive thought are often hard to prevent. Biases cannot always be avoided, since System 2 may have no clue as to the error. Even when cues to possible errors are available, errors can be prevented only by the effortful activity of System 2 (Kahneman, 2012). RubinsteinLevi and Kedar-Levy (2019) suggest that in the case of pension planning, the efforts involved are substantial, leading individuals to rely on System 1. The first manipulation in the experiments was designed to turn to System 2, and the second was designed to turn to System 1.

In Manipulation $X^{8}$, the respondents received an information page containing information regarding pension savings. The information was conveyed in a formal, informative approach, i.e., in the form of presenting facts and contexts.

In Manipulation $Y^{9}$, the respondents also received an information page containing information regarding pension savings. However, in this case, the information was conveyed in an informal approach, i.e., in the form of examples and implications.

Since pension savings is a complex issue that requires financial literacy, it is plausible that the lack of basic financial knowledge among employees causes them "Information overload" and "Choice overload". "Information overload" occurs when individuals are overwhelmed by information. "Choice overload" occurs when individuals are overwhelmed by choices. These effects prohibit employees from making educated decisions concerning their pension savings (Baddeley, 2017). Therefore, it is important to focus on simple retirement planning information (Banks and Oldfield, 2007). Accordingly, the information pages that the respondents received contained relatively little and specific information, only six short paragraphs. Those paragraphs provide information regarding the employees' responsibility for making pension savings decisions, the importance of saving for retirement from an early age, the effect of management fees on the future pension and the fact that management fees are negotiable, insurance components paid to the pension fund and their effect on the future pension, the correlation between risk and return and different investment tracks, and the low level of income from the old-age pension of the NII.

\section{The Groups}

The research included four groups, two Experimental Groups, and two Control Groups. Each Experimental Group received a different manipulation. Experimental Group 1 received Manipulation X, and Experimental Group 2 received Manipulation Y. Accordingly, each Control Group received a different manipulation. Control Group 1 received Manipulation $X$ and serves as a control group for Experimental Group 1. Control Group 2 received Manipulation $Y$ and serves as a control group for Experimental Group 2. One of the purposes of the Control Groups is to examine whether the pre-manipulation measurement in the Experimental Groups had an impact on the results. An additional purpose is to examine whether the use 
of different questions to measure the same variables before and after the manipulation in the Experimental Groups had an impact.

\section{Experimental Group 1}

STEP 1 - The respondents received a series of questions that would be referred to as "Questions Set 1"10. These questions were divided into four groups:

A. Questions that examined the respondents' knowledge regarding their pension savings.

B. Questions that examined whether the respondents pro-actively manage their pension savings, and if so, to what extent.

C. Questions that examined the respondents' willingness to manage their pension savings proactively and receive pension savings advice from a professional counselor.

D. Demographic questions.

STEP 2- The respondents received Manipulation $X$ - an information page containing six short paragraphs with information regarding pension savings, addressing System 2.

STEP 3- The respondents received an additional set of questions that would be referred to as "Questions Set 2"11. This set of questions measured the employees' willingness to recommend others to manage their pension savings pro-actively and their willingness to receive pension savings advice from a professional counselor on behalf of the state. The different versions of questions before the manipulation and after it, are intended to prevent bias that may arise due to respondents' desire to maintain consistency in their responses. However, they were formulated to measure the same variables.

\section{Experimental Group 2}

The respondents followed the same procedure as Experimental Group 1 and answered the same questions. The only difference is that this group received Manipulation $Y$.

\section{Control Group 1}

STEP 1- The respondents received Manipulation $X$.

STEP 2- The respondents received "Questions Set 1".

\section{Control Group 2}

STEP 1- The respondents received Manipulation $Y$.

STEP 2- The respondents received " Questions Set 1".

Figure 2 illustrates the Experimental Groups and the Control Groups according to manipulations and steps. 
FIGURE 2

\section{GROUPS BY MANIPULATIONS AND STEPS}

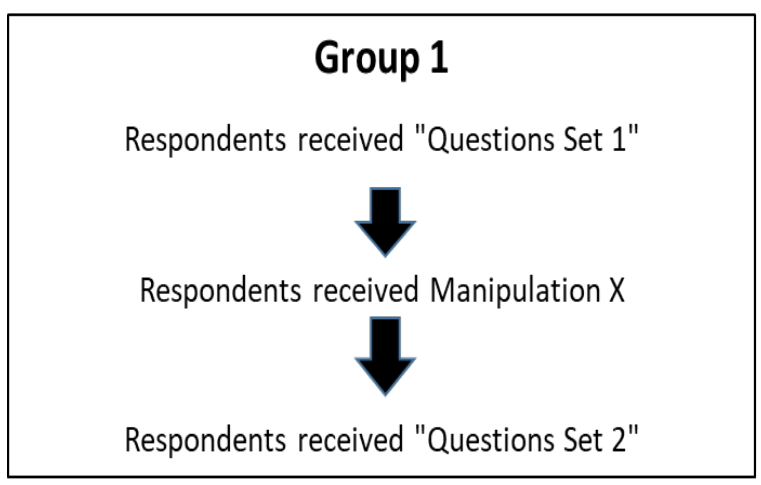

\section{Control group 1}

Respondents received Manipulation X

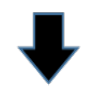

Respondents received "Questions Set 1"

\section{Group 2}

Respondents received "Questions Set 1"

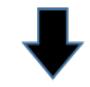

Respondents received Manipulation Y

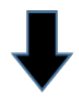

Respondents received "Questions Set 2"

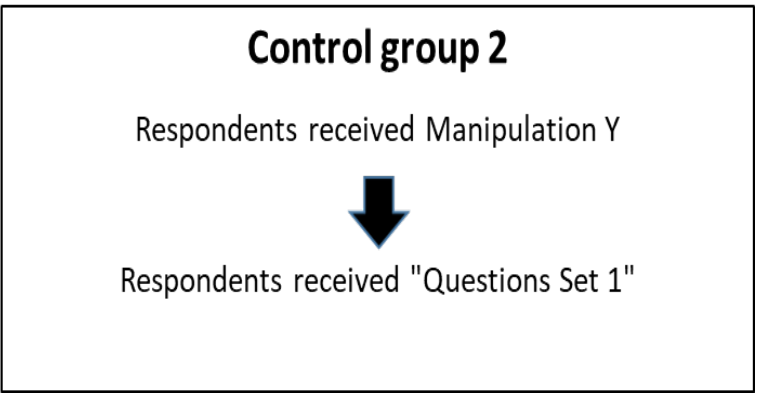

\section{RESULTS}

\section{Descriptive Statistics}

Table 1 presents a summary of the demographic variables in the Experimental Groups.

TABLE 1

DEMOGRAPHIC VARIABLES IN THE EXPERIMENTAL GROUPS, IN RATES

\begin{tabular}{lccc}
\hline Variable & weighted average & $\mathrm{G} 1^{13}$ & $\mathrm{G}^{12}$ \\
\hline Gender & & & \\
Male & $48 \%$ & $48 \%$ & $47 \%$ \\
Female & $52 \%$ & $52 \%$ & $53 \%$ \\
Marital status & & & \\
Married & $68 \%$ & $85 \%$ & $58 \%$ \\
Separated & $1 \%$ & $1 \%$ & $1 \%$ \\
Divorced & $4 \%$ & $6 \%$ & $3 \%$ \\
Widowed & $0 \%$ & $0 \%$ & $0 \%$ \\
Single & $28 \%$ & $8 \%$ & $39 \%$ \\
Age & & & \\
$20-30$ & $32 \%$ & $9 \%$ & $45 \%$ \\
$31-40$ & $29 \%$ & $23 \%$ & $33 \%$ \\
$41-50$ & $24 \%$ & $29 \%$ & $21 \%$ \\
\hline
\end{tabular}




\begin{tabular}{|c|c|c|c|}
\hline $51-60$ & $12 \%$ & $30 \%$ & $1 \%$ \\
\hline Over 60 & $3 \%$ & $9 \%$ & $0 \%$ \\
\hline \multicolumn{4}{|l|}{ Education } \\
\hline School completion certificate (not a matriculation certificate) & $7 \%$ & $8 \%$ & $6 \%$ \\
\hline Matriculation certificate & $24 \%$ & $15 \%$ & $29 \%$ \\
\hline Certificate of completion of a post-secondary non-academic school & $13 \%$ & $12 \%$ & $11 \%$ \\
\hline B.A. & $41 \%$ & $42 \%$ & $41 \%$ \\
\hline M.A. & $14 \%$ & $17 \%$ & $12 \%$ \\
\hline Ph.D. & $0 \%$ & $1 \%$ & $0 \%$ \\
\hline No certificate & $1 \%$ & $0 \%$ & $1 \%$ \\
\hline \multicolumn{4}{|l|}{ Gross monthly income in NIS } \\
\hline Up to 2,000 & $1 \%$ & $0 \%$ & $1 \%$ \\
\hline $2,001-3,000$ & $2 \%$ & $1 \%$ & $3 \%$ \\
\hline $3,001-4,000$ & $2 \%$ & $0 \%$ & $3 \%$ \\
\hline $4,001-5,000$ & $5 \%$ & $4 \%$ & $6 \%$ \\
\hline $5,001-6,000$ & $9 \%$ & $11 \%$ & $8 \%$ \\
\hline $6,001-7,500$ & $17 \%$ & $16 \%$ & $12 \%$ \\
\hline $7,501-10,000$ & $25 \%$ & $33 \%$ & $37 \%$ \\
\hline $10,001-14,000$ & $20 \%$ & $19 \%$ & $37 \%$ \\
\hline $14,001-21,000$ & $10 \%$ & $11 \%$ & $11 \%$ \\
\hline Over 21,000 & $10 \%$ & $5 \%$ & $14 \%$ \\
\hline
\end{tabular}

As can be seen in Table 1, the gender of the respondents in both groups is roughly evenly divided between men and women. Most of the respondents in both groups are married, but in Experimental Group 1, there are fewer single respondents than in Experimental Group 2. In Experimental Group 1, there are more older-aged respondents than in Experimental Group 2. Most of the respondents in both groups have a B.A., and most of them earn more than 7,500 New Israeli Shekels (NIS) ${ }^{14}$ and less than 14,001 NIS.

Table 2 presents a summary of the variables that measure the knowledge of the respondents regarding pension savings in the Experimental Groups.

TABLE 2

\section{KNOWLEDGE OF THE RESPONDENTS REGARDING PENSION SAVINGS IN THE EXPERIMENTAL GROUPS, IN RATES}

\begin{tabular}{llccc}
\hline Variable & Answers & $\begin{array}{c}\text { weighted } \\
\text { average }\end{array}$ & G1 & G2 \\
\hline $\begin{array}{l}\text { Do you know what percentage of salary } \\
\text { and/or }\end{array}$ & Know exactly & $30 \%$ & 15 & 37 \\
& & & $\%$ & $\%$ \\
how much of your salary you deposit to your & Know partially & $47 \%$ & 47 & 47 \\
& & & $\%$ & $\%$ \\
pension fund? & Do not know at all & $23 \%$ & 37 & 16 \\
Do you know how much management fee & Know exactly & $22 \%$ & $\%$ & $\%$ \\
you & & & 13 & 27 \\
& Know partially & $33 \%$ & 29 & 35 \\
pay to the pension fund? & & & $\%$ & $\%$ \\
\hline
\end{tabular}




\begin{tabular}{|c|c|c|c|c|}
\hline & Do not know at all & $45 \%$ & $\begin{array}{l}58 \\
\%\end{array}$ & $\begin{array}{l}38 \\
\%\end{array}$ \\
\hline \multirow{2}{*}{$\begin{array}{l}\text { Do you know what amount of monthly } \\
\text { pension }\end{array}$} & Know exactly & $7 \%$ & $9 \%$ & $7 \%$ \\
\hline & Know partially & $33 \%$ & 25 & 38 \\
\hline \multirow[t]{3}{*}{ you will receive upon retirement? } & & & $\%$ & $\%$ \\
\hline & Do not know at all & $60 \%$ & 66 & 56 \\
\hline & & & $\%$ & $\%$ \\
\hline \multirow{7}{*}{$\begin{array}{l}\text { Is the report you receive from the pension } \\
\text { fund } \\
\text { understandable? }\end{array}$} & & & 13 & 29 \\
\hline & Understandable & $24 \%$ & $\%$ & $\%$ \\
\hline & & & 58 & 42 \\
\hline & Not so understandable & $48 \%$ & $\%$ & $\%$ \\
\hline & Not at all & & 22 & 18 \\
\hline & understandable & $20 \%$ & $\%$ & $\%$ \\
\hline & Do not receive reports & $9 \%$ & $8 \%$ & $\%$ \\
\hline \multirow{5}{*}{$\begin{array}{l}\text { To what extent do you think your situation } \\
\text { will } \\
\text { worsen if the management fees you pay to } \\
\text { your }\end{array}$} & Greatly worsen & $58 \%$ & 56 & 60 \\
\hline & & & $\%$ & $\%$ \\
\hline & Moderately worsen & $30 \%$ & 29 & 30 \\
\hline & & & $\%$ & $\%$ \\
\hline & A little worse & $12 \%$ & 15 & 10 \\
\hline \multicolumn{2}{|l|}{ pension fund will increase by $1 \%$ ? } & & $\%$ & $\%$ \\
\hline \multirow{2}{*}{$\begin{array}{l}\text { How important is it to start saving for a } \\
\text { pension }\end{array}$} & Important & & 94 & 94 \\
\hline & & $94 \%$ & $\%$ & $\%$ \\
\hline \multirow[t]{3}{*}{ at a young age? } & Not so important & $5 \%$ & $5 \%$ & $5 \%$ \\
\hline & Not at all important & $1 \%$ & $1 \%$ & $1 \%$ \\
\hline & & & 66 & 68 \\
\hline \multirow[t]{2}{*}{ How important is it to report to your pension } & Important & $67 \%$ & $\%$ & $\%$ \\
\hline & & & 25 & 24 \\
\hline \multirow[t]{3}{*}{ fund on your marital status? } & Not so important & $24 \%$ & $\%$ & $\%$ \\
\hline & Not at all important & $9 \%$ & $9 \%$ & $8 \%$ \\
\hline & & & 60 & 71 \\
\hline \multirow[t]{2}{*}{ How important is it to change the investment } & Important & $67 \%$ & $\%$ & $\%$ \\
\hline & & & 34 & 27 \\
\hline \multirow[t]{2}{*}{ paths of the pension fund at different ages? } & Not so important & $30 \%$ & $\%$ & $\%$ \\
\hline & Not at all important & $3 \%$ & $7 \%$ & $2 \%$ \\
\hline \multirow{2}{*}{$\begin{array}{l}\text { How much do you think you will succeed } \\
\text { after }\end{array}$} & To a great extent & $4 \%$ & $3 \%$ & $5 \%$ \\
\hline & To a moderate extent & $27 \%$ & 29 & 26 \\
\hline \multirow[t]{2}{*}{ you retire, to maintain a standard of living } & & & $\%$ & $\%$ \\
\hline & To a small extent & $32 \%$ & 34 & 32 \\
\hline \multirow[t]{2}{*}{ similar to your standard of living before } & & & $\%$ & $\%$ \\
\hline & Not at all & & 34 & 37 \\
\hline $\begin{array}{l}\text { retirement, if your only income is from the } \\
\text { old-age pension of the NII? }\end{array}$ & & $36 \%$ & $\%$ & $\%$ \\
\hline
\end{tabular}


As can be seen in Table 2, most of the respondents have little or no knowledge regarding their pension savings. However, the respondents in Experimental Group 2 indicated greater knowledge than the respondents in Experimental Group 1. The vast majority of the respondents in both groups (94\%), understand that it is essential to start saving for retirement at a young age.

Table 3 presents a summary of the variables that measure the management of pension savings by the respondents in the Experimental Groups.

TABLE 3

PENSION SAVINGS MANAGEMENT OF THE RESPONDENTS IN THE EXPERIMENTAL GROUPS, IN RATES

\begin{tabular}{llccc}
\hline Variable & Answers & weighted average & G1 & G2 \\
\hline \multirow{2}{*}{$\begin{array}{l}\text { Do you monitor your pension } \\
\text { savings? }\end{array}$} & Often & $15 \%$ & $9 \%$ & $18 \%$ \\
& Rarely & $58 \%$ & $54 \%$ & $60 \%$ \\
& Never & $27 \%$ & $36 \%$ & $21 \%$ \\
Have you made any changes & & & \\
in your pension savings? & I transferred the funds from one & & \\
& pension fund to another & $21 \%$ & $16 \%$ & $24 \%$ \\
& I changed the savings path & $8 \%$ & $3 \%$ & $11 \%$ \\
& I changed management fees & $7 \%$ & $5 \%$ & $8 \%$ \\
& Other & $5 \%$ & $2 \%$ & $7 \%$ \\
& I made no change & $58 \%$ & $74 \%$ & $49 \%$ \\
\hline
\end{tabular}

As can be seen in Table 3, most of the respondents rarely monitor their pension savings and have never made any changes in it. More respondents in Experimental Group 1 than in Experimental Group 2, do not monitor their pension savings and have never made any changes in it.

Table 4 presents a summary of the variables that measure the attitudes of the respondents towards pension savings in the Experimental Groups.

\section{TABLE 4}

\section{ATTITUDES OF THE RESPONDENTS REGARDING PENSION SAVINGS IN THE EXPERIMENTAL GROUPS, IN RATES}

\begin{tabular}{llccc}
\hline Variable & Answers & weighted average & G1 & G2 \\
\hline Who do you think is primarily & The state & $34 \%$ & $52 \%$ & $23 \%$ \\
responsible for ensuring that & The workplace & $15 \%$ & $19 \%$ & $13 \%$ \\
retirees have a reasonable & The person himself / spouse & $47 \%$ & $23 \%$ & $61 \%$ \\
standard of living after & Other family members & $2 \%$ & $2 \%$ & $2 \%$ \\
retirement? & Other & $2 \%$ & $3 \%$ & $1 \%$ \\
& Important & $95 \%$ & $96 \%$ & $95 \%$ \\
How important is it to establish & Not so important & $3 \%$ & $2 \%$ & $4 \%$ \\
a government entity that will & Not at all important & $2 \%$ & $2 \%$ & $1 \%$ \\
supervise pension plans? & & & &
\end{tabular}


As can be seen in Table 4, more respondents in Experimental Group 1 than in Experimental Group 2, believe that the state is primarily responsible for ensuring retirees with a reasonable standard of living after retirement. The vast majority of the respondents in both groups, at a similar rate of about $95 \%$, think that it is important to establish an objective entity that will supervise pension plans.

Table 5 presents a summary of the variables that measure the willingness of the respondents to manage their pension savings pro-actively before the manipulation in the Experimental Groups.

TABLE 5

THE WILLINGNESS OF THE RESPONDENTS TO MANAGE THEIR PENSION SAVINGS PRO-ACTIVELY (BEFORE MANIPULATION) IN THE EXPERIMENTAL GROUPS, IN RATES

\begin{tabular}{llccc}
\hline Variable & Answers & weighted average & G1 & G2 \\
\hline $\begin{array}{l}\text { To what extent do you estimate that you } \\
\text { will manage your pension savings pro- }\end{array}$ & To a great extent & $24 \%$ & $27 \%$ & $23 \%$ \\
$\begin{array}{l}\text { actively, such as by haggling over } \\
\text { management fees, checking insurance }\end{array}$ & To a small extent & $40 \%$ & $31 \%$ & $44 \%$ \\
coverage, etc.? & Not at all & $29 \%$ & $29 \%$ & $29 \%$ \\
& & $7 \%$ & $13 \%$ & $3 \%$ \\
$\begin{array}{l}\text { Do you intend to receive pension savings } \\
\text { advice from a professional counselor? }\end{array}$ & Yes & & & \\
\hline
\end{tabular}

As can be seen in Table 5, most of the respondents in both groups estimated moderately that they will manage their pension savings pro-actively, and intend to receive pension advice.

The differences in some characteristics of the respondents in the Experimental Groups can be a factor in the results of the study. To neutralize the effect of these differences on the results, un-equal variances were assumed in the statistical analysis that compared the findings of the groups.

Table 6 presents a summary of the demographic variables in the Control Groups ${ }^{15}$.

TABLE 6

DEMOGRAPHIC VARIABLES IN THE CONTROL GROUPS, IN RATES

\begin{tabular}{lccc}
\hline Variable & weighted average & $\mathrm{C}^{17}$ & $\mathrm{C}^{16}$ \\
\hline Gender & & & \\
Male & $49 \%$ & $51 \%$ & $48 \%$ \\
Female & $51 \%$ & $49 \%$ & $52 \%$ \\
Marital status & & & \\
Married & $57 \%$ & $58 \%$ & $56 \%$ \\
Separated & $1 \%$ & $1 \%$ & $1 \%$ \\
Divorced & $5 \%$ & $5 \%$ & $4 \%$ \\
Widowed & $0 \%$ & $0 \%$ & $1 \%$ \\
Single & $37 \%$ & $36 \%$ & $38 \%$ \\
Age & & & \\
$20-30$ & $43 \%$ & $38 \%$ & $49 \%$ \\
$31-40$ & $32 \%$ & $31 \%$ & $34 \%$ \\
$41-50$ & $15 \%$ & $17 \%$ & $11 \%$ \\
$51-60$ & $7 \%$ & $10 \%$ & $5 \%$ \\
Over 60 & $3 \%$ & $4 \%$ & $1 \%$ \\
\hline
\end{tabular}




\begin{tabular}{|c|c|c|c|}
\hline \multicolumn{4}{|l|}{ Education } \\
\hline School completion certificate (not a matriculation certificate) & $6 \%$ & $4 \%$ & $8 \%$ \\
\hline Matriculation certificate & $31 \%$ & $30 \%$ & $32 \%$ \\
\hline Certificate of completion of a post-secondary non-academic school & $14 \%$ & $18 \%$ & $10 \%$ \\
\hline B.A & $38 \%$ & $40 \%$ & $36 \%$ \\
\hline M.A. & $9 \%$ & $7 \%$ & $12 \%$ \\
\hline Ph.D. & $1 \%$ & $0 \%$ & $2 \%$ \\
\hline No certificate & $1 \%$ & $1 \%$ & $2 \%$ \\
\hline \multicolumn{4}{|l|}{ Gross monthly income in NIS } \\
\hline Up to 2,000 & $1 \%$ & $3 \%$ & $0 \%$ \\
\hline $2,001-3,000$ & $4 \%$ & $5 \%$ & $3 \%$ \\
\hline $3,001-4,000$ & $2 \%$ & $2 \%$ & $3 \%$ \\
\hline $4,001-5,000$ & $7 \%$ & $9 \%$ & $6 \%$ \\
\hline $5,001-6,000$ & $10 \%$ & $9 \%$ & $10 \%$ \\
\hline $6,001-7,500$ & $11 \%$ & $9 \%$ & $12 \%$ \\
\hline $7,501-10,000$ & $27 \%$ & $24 \%$ & $31 \%$ \\
\hline $10,001-14,000$ & $14 \%$ & $14 \%$ & $15 \%$ \\
\hline $14,001-21,000$ & $17 \%$ & $18 \%$ & $16 \%$ \\
\hline Over 21,000 & $6 \%$ & $7 \%$ & $4 \%$ \\
\hline
\end{tabular}

As can be seen in Table 6, the gender of the respondents in both groups is roughly evenly divided between men and women. Most of the respondents in both groups are married. In Control Group 1, there are more older-aged respondents than in Control Group 2. Most of the respondents in both groups have a B.A., and most of them earn more than 7,500 NIS and less than 21,000 NIS.

The differences in some characteristics of the respondents in the Control Groups, compared to the Experimental Groups, can be a factor in the results of the study. To neutralize the effect of these differences on the results, unequal variances were assumed in the statistical analysis that compared the findings of the groups.

In summary, the data indicate that most of the respondents in all groups are aware of the importance of managing their pension savings. However, they tend not to manage it and have little knowledge regarding it, if any. More than $88 \%$ of the respondents think that their situation will worsen if the management fees they pay to the pension fund will be raised by one percent. However, more than $45 \%$ have no idea as to the management fees they pay, and only about $7 \%$ changed their management fees. More than $36 \%$ of the respondents think that they will not be able to maintain a standard of living similar to their standard of living before retirement if their income is only from old-age pensions of the NII. $32 \%$ think they will succeed only slightly. Nearly $60 \%$ of the respondents cannot estimate the monthly pension they will receive when they retire. About 58\% rarely monitor their pension savings, and $27 \%$ never monitor it. $67 \%$ of the respondents agree that it is important to change investment paths at different ages. More than $65 \%$ agree that it is important to report to the pension fund on changes in marital status. Yet, $58 \%$ have never made any changes to their pension plans. $9 \%$ do not receive reports from their pension fund. $20 \%$ do not understand the reports at all, $48 \%$ say the reports are not so understandable. $23 \%$ have no idea as to the amount of money or the percentage of wages they deposit in the pension fund. $47 \%$ know only partially.

The findings of the 2012 ICBS social survey are consistent with these findings. According to the ICBS's survey, $68 \%$ of the employees have no idea as to the management fees they pay to the pension fund. $62 \%$ have no idea what pension they will receive when they retire. $40 \%$ do not know what percentage of the salary they deposit to their pension fund. $13 \%$ do not understand the reports of the pension fund. $58 \%$ have never made any changes to their pension plans. Only $24 \%$ think to a large extent that they will be more proactive in managing their pension savings. $35 \%$ think that the main problem in the pension savings sector is 
that the pension terms and the employees' rights are not clear to the employees. $32 \%$ think the main problem is the lack of government supervision of pension arrangements. $25 \%$ think that the main problem is that the employee has no control over the funds in the pension fund. According to $8 \%$, the main problem is high management fees.

The ICBS survey shows that most of the Israeli employees divide the main problem of pension savings between two main factors, pension terms and the employees' rights, which are unclear to the employees, and the lack of government supervision over pension plans. The findings of this study indicate that these two factors may be closely related. Most employees are aware of the importance of pension savings and its effective management, and want to manage it more pro-actively (most of the respondents indicated that they intend to receive pension savings advice). However, their rights and the pension fund terms are unclear to them. This and the fact that $95 \%$ of the respondents in both surveys believe that it is very important to establish an objective government entity that will supervise pension funds may indicate that the employees expect "government protection" of their rights and interests.

\section{Analysis of the Results in the Experimental Groups}

For examining whether the manipulations affect the willingness of the respondents to manage their pension savings pro-actively, the answers to two questions in the Experimental Groups were compared, the first before the manipulation and the second after the manipulation. The question that was asked before the manipulation was, "To what extent do you estimate that you will more actively manage your pension savings, such as by haggling over management fees, checking insurance coverages, etc.?". The question that was asked after the manipulation was, "To what extent do you estimate that you will recommend to your family and/or friends to check their conditions in the pension fund and/or the management fees they pay, in order to examine the possibility of improving them?".

A paired-samples t-test was conducted to compare the willingness of the respondents to manage their pension savings pro-actively, before and after the manipulations. A significant difference was found in the scores before Manipulation $X(\mathrm{M}=2.188, \mathrm{SD}=0.681)$ and after Manipulation $X(\mathrm{M}=1.024, \mathrm{SD}=1.077)$ conditions; $\mathrm{t}(127)=11.75, \mathrm{p}<.05$. A significant difference was also found in the scores before Manipulation $Y(\mathrm{M}=2.077, \mathrm{SD}=0.852)$ and after Manipulation $Y(\mathrm{M}=1.217, \mathrm{SD}=0.712)$ conditions; $\mathrm{t}(220)=13.588$, $\mathrm{p}<.05$.

For examining whether the manipulations affect the willingness of the respondents to receive pension savings advice from a professional counselor, the answers to two questions were compared, the first before the manipulation and the second after the manipulation. The question that was asked before the manipulation was, "Do you intend to receive pension savings advice from a professional counselor?". The question that was asked after the manipulation was, "If you could receive pension savings advice from a professional counselor on behalf of the state, would you ask for advice?".

A chi-square test of independence was calculated, comparing the frequency of the respondents' responses regarding their intent to receive pension savings advice, before and after the manipulations.

A significant interaction was found regarding Manipulation $X\left(\chi^{2}(1)=174.376, p<.05\right)$ and regarding Manipulation $Y\left(\chi^{2}(1)=79.649, p<.05\right)$. More respondents, after Manipulation $X$, were interested in pension savings advice (95\%) than before (58\%). More respondents, after Manipulation $Y$, were interested in pension savings advice $(86 \%)$ than before $(53 \%)$.

\section{Income and Education}

Since education and income were found to be correlated with pension savings decisions (De Meza et al., 2008), the same tests were performed after controlling these variables. The respondents were divided into two groups by education and income. The first group, referred to as the 'low-education and low-income group', included employees with a salary of less than $10,000 \mathrm{NIS}^{18}$ and without an academic education. The second group, referred to as 'high-education and high-income group', included employees with a salary of 10,000 NIS or more and with academic education. In both groups and both variables, a significant difference in scores before and after both manipulations was found. 
'Low-Education and Low-Income Group'-

A paired-samples t-test was conducted to compare the willingness of the respondents to manage their pension savings pro-actively, before and after the manipulations. A significant difference was found in the scores before Manipulation $X(\mathrm{M}=2.139, \mathrm{SD}=1.037)$ and after Manipulation $X(\mathrm{M}=1.194, \mathrm{SD}=0.39)$ conditions; $\mathrm{t}(35)=6.86, \mathrm{p}<.05$. A significant difference was also found in the scores before Manipulation $Y(\mathrm{M}=2.092, \mathrm{SD}=0.741)$ and after Manipulation $Y(\mathrm{M}=1.292, \mathrm{SD}=0.241)$ conditions; $\mathrm{t}(128)=6.506, \mathrm{p}<.05$.

A chi-square test of independence was calculated, comparing the frequency of the respondents' responses regarding their intent to receive pension savings advice before and after the manipulations. A significant interaction was found regarding Manipulation $X\left(\chi^{2}(1)=11.872, p<.05\right)$ and regarding Manipulation $Y\left(\chi^{2}(1)=15.975, p<.05\right)$. More respondents, after Manipulation $X$, were interested in pension savings advice (94\%) than before (61\%). More respondents, after Manipulation $Y$, were interested in pension savings advice $(89 \%)$ than before $(58 \%)$.

\section{'High-Education and High-Income Group'-}

A paired-samples t-test was conducted to compare the willingness of the respondents to manage their pension savings pro-actively, before and after the manipulations. A significant difference was found in the scores before Manipulation $X(\mathrm{M}=2.371, \mathrm{SD}=0.887)$ and after Manipulation $X(\mathrm{M}=1.171, \mathrm{SD}=0.146)$ conditions; $\mathrm{t}(34)=7.141, \mathrm{p}<.05$. A significant difference was also found in the scores before Manipulation $Y(\mathrm{M}=2.035, \mathrm{SD}=0.534)$ and after Manipulation $Y(\mathrm{M}=1.421, \mathrm{SD}=0.391)$ conditions; $\mathrm{t}(56)=9.44, \mathrm{p}<.05$.

A chi-square test of independence was calculated, comparing the frequency of the respondents' responses regarding their intent to receive pension savings advice, before and after the manipulations. A significant interaction was found regarding Manipulation $X\left(\chi^{2}(1)=15.88, p<.05\right)$ and regarding Manipulation $Y\left(\chi^{2}(1)=21.34, p<.05\right)$. More respondents, after Manipulation $X$ were interested in pension savings advice $(97 \%)$ than before (57\%). More respondents, after Manipulation $Y$, were interested in pension savings advice $(90 \%)$ than before $(52 \%)$.

\section{Comparison Between the Effect of Manipulation X and Manipulation $Y$}

To examine whether there is a difference in the effect of the manipulations on the willingness of the respondents to manage their pension saving pro-actively, the answers to the question that followed the manipulation in the Experimental Groups " To what extent do you estimate that you will recommend to your family and/or friends to check their conditions in the pension fund and/or the management fees they pay, in order to examine the possibility of improving them?" were compared.

An independent-samples t-test was conducted to compare the willingness of the respondents to recommend family members and friends to manage their pension savings after Manipulation $X$ and after Manipulation $Y$. No significant difference was found in the scores for Manipulation $X(\mathrm{M}=1.248$, $\mathrm{SD}=0.533)$ and Manipulation $Y(\mathrm{M}=1.217, \mathrm{SD}=0.712)$ conditions; $\mathrm{t}(265)=\mathbf{0 . 4 3 0}, p=0.334$.

For examining whether there is a difference in the effect of the manipulations on the willingness of the respondents to receive pension savings advice, the answers to the question that followed the manipulation in the Experimental Groups, "If you could receive pension savings advice from a professional counselor on behalf of the state, would you ask for advice?", were compared.

A chi-square test of independence was calculated, comparing the frequency of the respondents' responses regarding their intent to receive pension savings advice, after Manipulation $X$, and after Manipulation $Y$. A significant interaction was found $\left(\chi^{2}(1)=21.698, p<.05\right)$. More respondents, after Manipulation $X$, were interested in pension savings advice (95\%) than after Manipulation $Y(86 \%)$.

Since the $\chi^{2}$ test does not weigh the magnitude of the change, compared to the preliminary (premanipulation) state in each group (unlike t-test), bias could have been created due to the differences in the preliminary situation in each of the groups. To examine whether such a bias was created, a comparison of the increase in the willingness of the respondents in the Experimental Groups to receive pension savings advice was made.

Table 7 presents the increase in the willingness of the respondents to receive pension savings advice in the Experimental Groups. 


\section{TABLE 7}

\section{THE INCREASE IN THE WILLINGNESS OF THE RESPONDENTS IN THE EXPERIMENTAL GROUPS TO RECEIVE PENSION SAVINGS ADVICE, IN RATES}

\begin{tabular}{cccc}
\hline & $\begin{array}{c}\text { Before } \\
\text { manipulation }\end{array}$ & $\begin{array}{c}\text { After } \\
\text { manipulation }\end{array}$ & $\begin{array}{c}\text { Rate of } \\
\text { increase }\end{array}$ \\
\hline $\mathrm{G} 1$ & $58 \%$ & $95 \%$ & $64 \%$ \\
$\mathrm{G} 2$ & $53 \%$ & $86 \%$ & $62 \%$ \\
\hline
\end{tabular}

As can be seen in Table 7, when comparing the rate of increase in the intent to receive pension savings advice from a professional counselor on behalf of the state, in Experimental Group 1 to the rate of increase in Experimental Group 2, the difference is only $2 \%$.

An independent-samples t-test was conducted to compare the increase in the intent to receive pension savings advice from a professional counselor on behalf of the state, in the Experimental Groups. No significant difference was found in the scores for Experimental Group $1(\mathrm{M}=0.512, \mathrm{SD}=0.639)$ and Experimental Group $2(\mathrm{M}=0.496, \mathrm{SD}=0.651)$ conditions; $\mathrm{t}(256)=0.430, p=.424$.

In summary, both manipulations had a significant effect on the willingness of the respondents to manage their pension savings pro-actively and to receive pension savings advice. No significant differences were found in the effect of the manipulations.

\section{Analysis of the Control Groups}

Since one of the goals of the Control Groups is to examine whether the pre-manipulation measurement ("Question Set 1") in the Experimental Groups had an impact on the results, a pre-manipulation measurement was not performed in the Control Groups. The responses of the respondents to the questions that followed the manipulation in Control Group 1 (Question Set 1) were compared to the pre-manipulation responses of the respondents in Experimental Group 1 (Question Set 1). The responses of the respondents that followed the manipulation in Control Group 2 (Question Set 1) were compared to the pre-manipulation responses of the respondents in Experimental Group 2 (Question Set 1), assuming equal variances.

Table 8 presents the willingness of the respondents to manage their pension savings pro-actively in the Control Groups.

\section{TABLE 8 \\ THE EFFECT OF THE MANIPULATIONS IN THE CONTROL GROUPS - THE WILLINGNESS OF THE RESPONDENTS TO PRO-ACTIVELY MANAGE THEIR PENSION SAVINGS, IN RATES}

\begin{tabular}{lcccc}
\hline Answer & G1 & C1 & G2 & C2 \\
\hline To a great extent & $24 \%$ & $26 \%$ & $24 \%$ & $29 \%$ \\
To a moderate extent & $40 \%$ & $41 \%$ & $40 \%$ & $42 \%$ \\
To a small extent & $29 \%$ & $26 \%$ & $29 \%$ & $25 \%$ \\
Not at all & $7 \%$ & $7 \%$ & $7 \%$ & $4 \%$ \\
\hline
\end{tabular}

A paired-samples t-test was conducted to compare the willingness of the respondents to manage their pension savings pro-actively, before and after Manipulation X. For this purpose, the pre-manipulation question in Experimental Group 1 was compared to the post-manipulation question in Control Group 1. A paired-samples t-test was also conducted to compare the willingness of the respondents to manage their pension savings pro-actively, before and after Manipulation Y. For this purpose, the pre-manipulation 
question in Experimental Group 2 was compared to the post-manipulation question in Control Group 2. No significant difference was found in the scores before Manipulation X $(\mathrm{M}=2.132, \mathrm{SD}=1.017)$ and after Manipulation $X(M=2.052, S D=0.960)$ conditions; $t(211)=0.855, p=0.197$. Similarly, no significant difference was found in the scores before Manipulation $\mathrm{Y}(\mathrm{M}=2.066, \mathrm{SD}=0.892)$ and after Manipulation $\mathrm{Y}$ $(\mathrm{M}=2.017, \mathrm{SD}=0.891)$ conditions; $\mathrm{t}(180)=0.538, \mathrm{p}=0.296$.

A chi-square test of independence was calculated, comparing the frequency of the respondents' responses regarding their intent to receive pension savings advice before and after the manipulations. No significant interaction was found regarding Manipulation $\mathrm{X}\left(\chi^{2}(1)=.085, \mathrm{p}>.05\right)$. More respondents after Manipulation X were interested in pension savings advice (55\%) than before (54\%), but not significantly. Similarly, no significant interaction was found regarding Manipulation $Y\left(\chi^{2}(1)=.327, p>.05\right)$. More respondents after Manipulation $Y$ were interested in pension savings advice (56\%) than before (54\%), but not significantly.

Manipulation X and Manipulation Y were found influential in the Experimental Groups, however, had no significant effect in the Control Groups.

There are several possible explanations for the different results in the Experimental Groups compared to the Control Groups:

1. The pre-manipulation measurement ("Question Set 1") in the Experimental Groups had an impact on the results.

2. Equivalence of variances cannot be assumed regarding Experimental Group 1 and Control Group 1, Experimental Group 2 and Control Group 2, and Control Group 1 and Control Group 2 .

3. The use of different versions of questions for the same variables before the manipulation and after it was an influential factor.

It should be noted that several of the above factors may have affected the results simultaneously.

For examining the explanations suggested above, it is necessary to examine whether there was a significant difference in the willingness of the respondents to manage their pension savings pro-actively and receive pension savings advice from a professional in Control Group 1, compared to Control Group 2. Lack of difference reduces the likelihood that the differences in the findings (Experimental Groups vs. Control Groups) were due to the assumption of equal variances; and increases the likelihood that the cause was the use of different versions of questions for the same variables before the manipulation and after it, in the Experimental Groups.

The Effect of Manipulation X Compared to the Effect of Manipulation Y in the Control Groups

Table 9 presents the willingness of the respondents in the Control Groups to manage their pension savings pro-actively.

TABLE 9

COMPARISON BETWEEN CONTROL GROUP 1 AND 2-THE WILLINGNESS OF THE RESPONDENTS TO PRO-ACTIVELY MANAGE THEIR PENSION SAVINGS, IN RATES

\begin{tabular}{lcc}
\hline Answer & $\mathrm{C} 1$ & $\mathrm{C} 2$ \\
\hline To a great extent & $26 \%$ & $29 \%$ \\
To a moderate extent & $41 \%$ & $42 \%$ \\
To a small extent & $26 \%$ & $25 \%$ \\
Not at all & $7 \%$ & $4 \%$ \\
\hline
\end{tabular}

An independent-samples t-test was conducted to compare the willingness of the respondents to proactively manage their pension savings, after Manipulation X (in Control Group 1) and after Manipulation 
$Y$ (in Control Group 2). No significant difference was found in the scores for Manipulation $X(\mathrm{M}=2.132$, $\mathrm{SD}=0.884)$ and Manipulation $Y(\mathrm{M}=2.062, \mathrm{SD}=0.847)$ conditions; $\mathrm{t}(380)=0.782, p=0.218$.

A chi-square test of independence was calculated, comparing the frequency of the respondents' responses regarding their intent to receive pension savings advice after Manipulation $X$ and after Manipulation $Y$. No significant interaction was found $\left(\chi^{2}(1)=.088, p>.05\right)$. The respondents who received Manipulation $Y$ were more interested in pension savings advice $(56 \%)$ than the respondents who received Manipulation $X(55 \%)$, but not significantly.

The findings indicate that there is no significant difference between the Control Groups in the respondents' willingness to manage their pension saving pro-actively and receive pension savings advice. These findings reduce the likelihood that the factor explaining the differences in the findings of the Experimental Groups, and the Control Groups, is the assumption of equal variances. However, it does not eliminate it. The findings raise the likelihood that the use of different versions of questions for the same variables before the manipulation and after it in the Experimental Groups, was an influential factor, as opposed to the Control Groups, where the same questions were compared.

In summary, both manipulations were found to have a significant effect on the willingness of the respondents to manage their pension savings pro-actively and receive pension savings advice, in the Experimental Groups. The effect of Manipulation $X$ compared to Manipulation $Y$ is not significantly different. This finding is consistent with the study of Painton and Gentry (1985), which showed that the process of acquiring information does not necessarily depend on how the information is presented. The finding is also consistent with the study of Speier (2006), which showed that the complexity of the task moderates the relationship between information presentation format and decision performance.

Surprisingly, in the Control Groups, the manipulations did not have a significant effect on the willingness of the respondents to manage their pension savings pro-actively and receive pension savings advice. Several possible explanations for the differences between the Experimental Groups and the Control Groups were suggested. The more likely explanation is the use of different versions of questions for the same variables before the manipulation and after it, in the Experimental Groups.

The findings of this study indicate that most of the respondents, before the manipulations, were already aware of the importance of pension savings management. This may explain why the manipulations did not affect the respondents' willingness to manage their pension savings pro-actively, and why the respondents were more willing to recommend others to pro-actively manage their pension savings and less willing to do so themselves. The findings of the social survey, according to which, most employees think that the state is the main factor responsible for ensuring retirees with a reasonable standard of living, and the desire of employees in governmental supervision of pension plans, may explain why more employees are willing to receive pension savings advice from a professional counselor on behalf of the state than from a professional counselor who is not necessarily on behalf of the state.

\section{DISCUSSION AND SUMMARY}

This study concludes that the transfer of the information regarding pension savings to employees, regardless of the method being used to transfer information, does not significantly increase their willingness to manage their pension savings pro-actively and receive pension savings advice from a professional.

Surprisingly, the findings indicate that in a difference of $63 \%$ on average, more employees are willing to receive pension savings advice from a professional counselor on behalf of the state $(91 \%)$ than from a professional counselor who is not necessarily on behalf of the state $(56 \%)$.

Studies on pension savings can offer an explanation for the employees' apparent preference for receiving advice from a professional counselor who is on behalf of the state over one who is not necessarily on behalf of the state.

Employees are likely to encounter financial counselors who have a conflict of interest and who may provide advice that is not in their best interests (Turner et al., 2016). Most employees are aware of the risks involved in receiving pension savings advice and the bias that can arise in their decision-making regarding pension savings (Jolls et al., 1997). Therefore, they minimize the joint cost of effort and error in making a 
decision (Vessey, 1994). The weight they give to information depends significantly on the perceived authority of the source of that information (Dolan et al., 2012), and they prefer to speak one-on-one with trusted professionals (Agnew, 2006).

Around the world, there is intense debate about how to structure the marketplace for pension savings advice, along with a regulatory renaissance generating many new rules to address the problems of unaffordable, conflicted, or offering unclear value proposition counselors. The United-Kingdom and Australia have recently passed laws that ban the commission-based selling of investment advice due to conflict of interest. Germany appears to be making strides in that direction as well, and in the united states, the movement toward less conflicted advice has several fronts (Mitchell and Smetters, 2013). However, existing regulatory standards, as they currently are enforced, are not adequate to protect pension participants from seriously bad advice. Moreover, the fiduciary standard cannot guarantee good advice, and bad advice can be very costly (Turner et al., 2016).

If regulation is to be beneficial, it must be tailored to specific problems (Campbell et al., 2011). The findings of this study suggest that governments should consider providing employees with pension savings advice from a counselor on behalf of the state to improve the financial situation of retirees. Since employees with low-education and low-income tend to ask for pension savings advice less than employees with higheducation and high-income (De Meza et al., 2008), providing the public with such advice on behalf of the state will also help to reduce poverty and inequality in the population of retirees.

\section{ACKNOWLEDGEMENTS}

I thank Haim Kedar-Levy, Moshe Arye Milevsky, and participants of the Symposium on Psychology and Economics (TIBER) 2018, Tilburg University, The Netherlands; The 4th Coller Conference on Behavioral Economics (CCBE) 2019, Tel Aviv University, Israel; Subjective Probability, Utility, and Decision Making (SPUDM) 2019 conference, University of Amsterdam, The Netherlands and the Society for Advancement of Behavioral Economics (SABE) 2020 conference, for many helpful comments and suggestions.

\section{ENDNOTES}

1. Source: OECD (2018), Household spending (indicator). doi: 10.1787/b5f46047-en.

2. Source :OECD (2019), Poverty rate (indicator). doi: 10.1787/0fe1315d-en.

3. Source: NII report on the dimensions of poverty and social gaps in Israel, 2017.

4. Source: OECD (2015), Pensions at a Glance 2015: OECD and G20 indicators, OECD Publishing, Paris.

5. Source: The social survey of the ICBS for 2012 (see Appendix A).

6. Source: NII report on government payments to retirees 1955-2018, 2019.

7. A detailed description of the survey and the sampling method can be found in Appendix A.

8. Manipulation $X$ can be found in Appendix B.

9. Manipulation $Y$ can be found in Appendix C.

10. "Questions Set 1" can be found in Appendix D.

11. "Questions Set 2" can be found in Appendix E.

12. G1 means Experimental Group 1. N=308.

13. G2 means Experimental Group 2. N=392.

14. 1 NIS equals about 0.28 USD.

15. In the Control Groups, only demographic variables were compared, since non-demographic variables, were measured after the manipulation, and therefore may have been affected by it.

16. C1 means Control Group 1. N=425.

17. C2 means Control Group 2. N=394.

18. The average wage in Israel in 2016 was approximately 10,000 NIS. 


\section{REFERENCES}

Achdut, L., \& Spivak, A. (2010). The pension system in Israel after fifteen years of reform. The Van Leer Institute.

Agnew, J. (2006). Personalized Retirement Advice and Managed Accounts: Who Uses Them and How Does Advice Affect Behavior in 401 (k) Plans? Center for Retirement Research Working Papers, 120.

Agnew, J. (2013). Australia's retirement system: Strengths, weaknesses, and reforms. Center for Retirement Research Issue Brief, pp. 13-5.

Agnew, J.R., \& Szykman, L.R. (2005). Asset allocation and information overload: The influence of information display, asset choice, and investor experience. The Journal of Behavioral Finance, $6(2), 57-70$.

Baddeley M. (2017). Behavioral economics. Oxford University Press.

Banks, J., \& Oldfield, Z. (2007). Understanding pensions: Cognitive function, numerical ability and retirement saving. Fiscal Studies, 28(2), 143-170.

Been, J., Caminada, K., Goudswaard, K., \& van Vliet, O. (2017). Public/private pension mix, income inequality and poverty among the elderly in Europe: An empirical analysis using new and revised OECD data. Social Policy \& Administration, 51(7), 1079-1100.

Benartzi, S., \& Thaler, R.H. (2001). Naive diversification strategies in defined contribution saving plans. American Economic Review, 91(1), 79-98.

Benartzi, S., \& Thaler, R.H. (2002). How much is investor autonomy worth? The Journal of Finance, 57(4), 1593-1616.

Benartzi, S., \& Thaler, R. (2007). Heuristics and biases in retirement savings behavior. Journal of Economic Perspectives, 21(3), 81-104.

Bettman, J.R., \& Kakkar, P. (1977). Effects of information presentation format on consumer information acquisition strategies. Journal of Consumer Research, 3(4), 233-240.

Bleikh H. (2016). Poverty and inequality in Israel: An international perspective. In D. Chernichovsky \& A. Weiss (Eds.), State of the nation report: Society, economy and policy in Israel 2015: Vol. 4. Social welfare (pp. 353-392). Taub Center for social policy studies in Israel, the Herbert M. Singer annual report Series.

Bodie, Z., \& Merton, R.C. (1992). Pension Reform and Privatization in International Perspective: The Case of Israel. Division of Research, Harvard Business School.

Brender, A. (2011). First year of the mandatory pension arrangement: Compliance with the arrangement as an indication of its potential implications for labor supply. Research Department, Bank of Israel.

Bubb, R., \& Pildes, R.H. (2013). How behavioral economics trims its sails and why. Harv. L. Rev., 127, 1593.

Burks, S.V., Carpenter, J.P., Goette, L., \& Rustichini, A. (2009). Cognitive skills affect economic preferences, strategic behavior, and job attachment. Proceedings of the National Academy of Sciences, 106(19), 7745-7750.

Byrne A. (2007) Employee saving and investment decisions in defined contribution pension plans: Survey evidence from the U.K. Financial Services Review, 16, 19-41.

Campbell, J.Y., Jackson, H.E., Madrian, B.C., \& Tufano, P. (2011). Consumer financial protection. Journal of Economic Perspectives, 25(1), 91-114.

Carroll, G.D., Choi, J.J., Laibson, D., Madrian, B.C., \& Metrick, A. (2009). Optimal defaults and active decisions. The Quarterly Journal of Economics, 124(4), 1639-1674.

Choi J.J. (2015). Contributions to defined contribution pension plans. Annual Review of Financial Economics, 7(1), 161-178.

Choi, J.J., Laibson, D., \& Madrian, B.C. (2004). Plan design and 401 (k) savings outcomes (No. w10486). National Bureau of Economic Research. 
Choi, J.J., Laibson, D., Madrian, B.C., \& Metrick, A. (2002). Defined contribution pensions: Plan rules, participant choices, and the path of least resistance. Tax Policy and the Economy, 16, 67-113.

De Meza, D., Irlenbusch, B., \& Reyniers, D. (2008). Financial capability: A behavioral economics perspective. Consumer Research, 69, 192-193.

Dolan, P., Hallsworth, M., Halpern, D., King, D., Metcalfe, R., \& Vlaev, I. (2012). Influencing behaviour: The mindspace way. Journal of Economic Psychology, 33(1), 264-277.

Ellis C.D., Munnell A.H. \& Eschtruth A.D. (2015). Falling short: The coming retirement crisis and what to do about it. Oxford University Press.

Gavious, I., Spivak, A., \& Yosef, R. (2009). Pension reform in Israel under mandatory pension law. Pensions: An International Journal, 14(1), 4-13.

Gharghori P., Madhu S.C., \& Veeraraghavan M. (2008). Are Australian investors smart? Australian Journal of Management, 32(3), 525-544.

Ghilarducci T., Saad-Lessler J. \& Bahn K. (2015, Winter). Are U.S. workers ready for retirement? Trends in plan sponsorship, participation, and preparedness. Journal of Pension Benefits, pp. 25-39.

Gunaratne, J., \& Nov, O. (2015, June). Influencing retirement saving behavior with expert advice and social comparison as persuasive techniques. In International Conference on Persuasive Technology (pp. 205-216). Springer, Cham.

Harrison T., Waite K., \& White P. (2006). Analysis by paralysis: The pension purchase decision process. The International Journal of Bank Marketing, 24, 5-24.

Hung, A., \& Yoong, J. (2013). Asking for help: Survey and experimental evidence on financial advice and behavior change. The Market for Retirement Financial Advice, 182.

Jenkins V. (2005). Educating employers to make informed choice about financial education. Pensions: An International Journal, 10, 331-336.

Jolls, C., Sunstein, C.R., \& Thaler, R. (1997). A behavioral approach to law and economics. Stan. L. Rev., $50,1471$.

Kahneman, D. (2012). Thinking, fast and slow New York: Penguin Press.

Kahneman, D., \& Riepe, M.W. (1998). Aspects of investor psychology. Journal of Portfolio Management, 24(4), 52-+.

Knoll, M.A. (2010). The role of behavioral economics and behavioral decision making in Americans' retirement savings decisions. Soc. Sec. Bull., 70, 1.

Lusardi, A. (2008). Financial literacy: An essential tool for informed consumer choice? (No. w14084). National Bureau of Economic Research.

Lusardi, A., \& Mitchell, O.S. (2009). How ordinary consumers make complex economic decisions: Financial literacy and retirement readiness (No. w15350). National Bureau of Economic Research.

Madrian, B.C., \& Shea, D.F. (2001). The power of suggestion: Inertia in 401 (k) participation and savings behavior. The Quarterly Journal of Economics, 116(4), 1149-1187.

Miles, D., Timmermann, A., de Haan, J., \& Pagano, M. (1999). Risk sharing and transition costs in the reform of pension systems in Europe. Economic Policy, pp. 253-286.

Mitchell, O.S., \& Smetters, K. (Eds.). (2013). The market for retirement financial advice. OUP Oxford.

Oehler A. \& Werner C. (2008). Saving for retirement - A case for financial education in Germany and U.K. An economic perspective. Journal of Consumer Policy, 31, 253-284.

Painton, S., \& Gentry, J.W. (1985). Another look at the impact of information presentation format. Journal of Consumer Research, 12(2), 240-244.

Rubinstein-Levi, R. \& Kedar-Levy, H. (2019). The effect of attitudes regarding retirement on pension savings. Review of Economics and Finance, 15(1), 1-13.

Saez, E. (2009). Details matter: The impact of presentation and information on the take-up of financial incentives for retirement saving. American Economic Journal: Economic Policy, 1(1), 204-28.

Sewin C. (2008). What you don't know can't help you: Pension knowledge and retirement decisionmaking. The Review of Economics and Statistics, 90, 253-266.

Journal of Applied Business and Economics Vol. 23(3) 2021355 
Speier, C. (2006). The influence of information presentation formats on complex task decision-making performance. International Journal of Human-Computer Studies, 64(11), 1115-1131.

Sunstein, C.R., \& Thaler, R.H. (2003). Libertarian paternalism is not an oxymoron. The University of Chicago Law Review, pp. 1159-1202.

Thaler, R.H. (1994). Psychology and savings policies. The American Economic Review, 84(2), 186-192.

Thaler, R.H., \& Benartzi, S. (2004). Save more tomorrow ${ }^{\mathrm{TM}}$ : Using behavioral economics to increase employee saving. Journal of Political Economy, 112(S1), S164-S187.

Thaler, R.H., \& Benartzi, S. (2007). The Behavioral Economics of Retirement Savings Behavior. AARP Issue Paper no. 2007-02. Washington, DC: AARP Public Policy Institute.

Turner, J.A., Klein, B.W., \& Stein, N.P. (2016). Financial Illiteracy Meets Conflicted Advice: The Case of Thrift Savings Plan Rollovers. The Journal of Retirement, 3(4), 47-65.

Van Rooij, M.C., Lusardi, A., \& Alessie, R.J. (2012). Financial literacy, retirement planning and household wealth. The Economic Journal, 122(560), 449-478.

Vessey, I. (1994). The effect of information presentation on decision making: A cost-benefit analysis. Information \& Management, 27(2), 103-119.

\section{APPENDICES}

\section{Appendix A. The Social Surveys of the ICBS}

The Social Survey has been conducted annually since 2002 on a sample of persons aged 20 and older. The main purpose of the Social Survey is to provide up-to-date information on the welfare of Israelis and their living conditions. The social survey questionnaire has two main parts: a core questionnaire containing about 200 items covering the main areas of life such as health, housing, employment, economic situation, and a variable module devoted to a different topic each year to investigate it in greater detail than is possible in the core questionnaire. The questionnaires are administered by ICBS interviewers using laptops to conduct computer-assisted personal interviews (CAPI). The interviews are conducted in Hebrew, Arabic, and Russian. An interview lasts about an hour. The table generator allows for deriving both estimates of persons and households. The survey population comprises the permanent non-institutional population of Israel aged 20 and older, as well as residents of non-custodial institutions (such as student dormitories, immigrant absorption centers, and independent living projects for the elderly). New immigrants are included in the survey population if they have been present in Israel for at least six months. Groups not included in survey population: residents of custodial institutions (eg., nursing homes, hospitals for the chronically ill, prisons), Israelis abroad for more than a year without interruption at the time of the survey, diplomats, new immigrants who arrived fewer than six months before the interview, Bedouin tribes' residents, and others living outside the boundaries of localities. The Social Survey is the first survey conducted by the ICBS using the Population Register as a sampling frame. In general, the quality of the sampling frame depends on the degree to which it covers the survey population: under-coverage can lead to biased estimates, while over-coverage leads to higher costs because of attempts to enumerate persons who are not part of the survey population. Therefore, persons not belonging to the survey population were removed from the sampling frame. The desired final sample size for each year is 7,500 persons aged 20 and older. The expected size of each design group was to be proportional to its size in the population, under the constraint of a final total sample size of 7,500 completed interviews. The initial sample includes about 9,500 persons to obtain 7,500 respondents. Data collected in the Social Survey come from a sample of the population. To provide estimates based on the survey for the total population and sub-groups, it is necessary to compute for each person a weight, which reflects the number of persons in the population whom he "represents". In the present form of the table generator, weights of a person divided by the number of persons in the household aged 20 and overexpresses the estimated number of households in the population whom he "represents", thus allowing the derivation of estimates of households. The method of estimation takes into consideration both the sampling method and the difficulties in data collection. The estimation method is intended primarily to minimize bias resulting from informative non-response, from undercoverage of specific groups, and variations in sample size according to characteristics (such as education 
or labor force participation), which were not taken into account in the sample design. The estimation procedure involved three stages: First, each respondent received an initial weight, which was the inverse of their sampling probability, as a correction for non-response. The initial weight reflects the differential sample design and the differential response in a narrow geographical cross-section. To carry out the second stage, adjustment variables were selected. The distribution of these variables was known from administrative sources or was estimated from the Monthly Labor Force Survey, and they had the strongest correlation with the most important variables included in the Social Survey core questionnaire. Thirdly, final weights were computed by the method of "raking", in which the distribution of the weighted sample obtained from the second stage was adjusted to the distributions of five external estimates: 1. Estimates of households by population group: extended household size -38 groups. 2. Estimates of persons aged 20 and over by population group: sex and marital status -12 groups. 3 . Estimates of persons aged 20 and over by population group: labor force characteristics and education - 11 groups. 4. Estimates of persons aged 20 and over by population group: geographical groups and distinction between the ultra-Orthodox population, based on administrative sources (according to educational institutions) and the rest of the population (for persons aged 20-64): for persons in Jewish and mixed localities - 27 groups. 5. Estimates of persons aged 20 and over by population group: geographical groups, sex, and age groups -234 groups.

\section{Appendix B. Manipulation $X$}

Information Page Regarding Pension Savings

Here is some information regarding pension savings:

* The employees bear the responsibility for their pension savings and not the government or the employees' place of work. Decisions that the employees make or do not make, affect their economic situation upon retirement.

* The younger an employee starts to save for a pension, the higher the probability that his/her income from a pension will allow him/her to maintain the same standard of living he/she had before retirement.

* Employees who pay maximum management fees to their pension funds will receive pensions that are lower by more than ten percent than employees who pay reduced management fees. Management fees are negotiable.

* Employees pay their pension funds for different insurance coverages that reduce their future pensions. Sometimes, some of these payments are unnecessary, and they are non-refundable.

* The employees' savings in pension funds can be invested in different investment tracks. The higher the risk in the investment track, the higher the return.

* The maximum old-age pension of the National Insurance Institute is less than one-third of the average salary.

\section{Appendix C. Manipulation $Y$}

Information Page Regarding Pension Savings

Here are some facts regarding pension savings:

* About $30 \%$ of the elderly population in Israel is below the poverty line. One of the reasons for that is that most employees avoid making decisions regarding their pension savings and hold the government/their place of work responsible for maintaining them a reasonable standard of living upon retirement.

* An employee that earns 7,500 NIS a month and starts saving for a pension at the age of 25 will probably receive a pension of over 7,000 NIS. This means that his/her standard of living will hardly change. However, if the employee starts saving at 45 , his/her monthly pension will probably reach only about 2,600 NIS.

* The pensions of an employee that earns 7,500 NIS a month and pays maximum management fees will be lower than the pension of an employee with the same income however pays reduced management fees in more than 1,000 NIS. Management fees are negotiable. 
An employee who does not report his/her family status to the pension fund automatically pays for widow insurance. This payment is non-refundable and unnecessary for single employees, and it reduces their monthly pension by hundreds of NIS per month.

* An employee who invests his/her pension savings in a high-risk investment track can receive a higher pension of more than $20 \%$ than an employee who invests his/her pension savings in a low-risk investment track.

* The maximum old-age pension of the National Insurance Institute is about 3,000 NIS.

\section{Appendix D. "Question Set 1"}

1. Do you know what percentage of salary and/or how much of your salary you deposit to your pension fund?

1. Know exactly

2. Know partially

3. Do not know at all

2. Do you know how much management fee you pay to the pension fund?

1. Know exactly

2. Know partially

3. Do not know at all

3. Do you know what amount of monthly pension you will receive upon retirement?

1. Know exactly

2. Know partially

3. Do not know at all

4. Is the report you receive from the pension fund understandable?

1. The report is understandable

2. The report is not so understandable

3. The report is not at all understandable

4. I do not receive reports

5. To what extent do you think your situation will worsen if the management fees you pay to your pension fund will increase by $1 \%$ ?

1. Greatly worsen

2. Moderately worsen

3. A little worse

6. How important is it to start saving for a pension at a young age?

1. Important

2. Not so important

3. Not at all important

7. How important is it to report to your pension fund on your marital status?

1. Important

2. Not so important

3. Not at all important

8. How important is it to change the investment paths of the pension fund at different ages?

1. Important

2. Not so important

3. Not at all important

9. How much do you think you will succeed after you retire, to maintain a standard of living similar to your standard of living before retirement, if your only income is from the old-age pension of the NII?

1. To a great extent

2. To a moderate extent

3. To a small extent

4. Not at all 
10. Do you monitor your pension savings?
1. Often
2. Rarely
3. Never

11. Have you made any changes in your pension savings?

1. I transferred the funds from one pension fund to another

2. I changed the savings path

3. I changed management fees

4. Other

5. I made no change

12. Who do you think is primarily responsible for ensuring that retirees have a reasonable standard of living after retirement?

1. The state

2. The workplace

3. The person himself / spouse

4. Other family members

5. Other

13. How important is it to establish a government entity that will supervise pension plans?

1. Important

2. Not so important

3. Not at all important

14. To what extent do you estimate that you will more actively manage your pension savings, such as by haggling over management fees, checking insurance coverages, etc.?

1. To a great extent

2. To a moderate extent

3. To a small extent

4. Not at all

15. Do you intend to receive pension savings advice from a professional counselor?

1. Yes

2. No

16. You are:

1. Male

2. Female

17. What is your age?

18. What is your marital status?

1. Married

2. Separated

3. Divorced

4. Widowed

5. Single

19. What is the highest certificate or degree that you have received?

1. School completion certificate (not a matriculation certificate)

2. Matriculation certificate

3. Certificate of completion of a post-secondary non-academic school

4. B.A.

5. M.A.

6. Ph.D.

7. No certificate

20. What is your gross monthly income? 


\section{Appendix E. "Question Set 2"}

1. To what extent do you estimate that you will recommend to your family and/or friends to check their conditions in the pension fund and/or the management fees they pay, to examine the possibility of improving them?

1. To a great extent

2. To a moderate extent

3. To a small extent

4. Not at all

2. If you could receive pension savings advice from a professional counselor on behalf of the state, would you ask for advice?

1. Yes

2. No 